\title{
Evaluation and storage studies of sausage roll produced from wheat-ti- gernut flour blends
}

\author{
Emmanuel Kehinde Oke ${ }^{1 *}$, Michael Ayodele Idowu ${ }^{1}$, Abiodun Aderoju Adeola² ${ }^{2}$ Temitope Omowumi Abiola ${ }^{1}$, Ibrahim \\ Ololade Adeniji ${ }^{1}$
}

\begin{abstract}
${ }^{1}$ Department of Food Science and Technology, Federal University of Agriculture, Abeokuta, Ogun State, Nigeria ${ }^{2}$ Food and Nutrition Research Programme, Institute of Food Security, Environmental Resources and Agricultural Research, Federal University of Agriculture, Abeokuta, Ogun State, Nigeria.
\end{abstract}

${ }^{*}$ Corresponding author:kennyoke35@gmail.com

\begin{abstract}
This study was carried out to investigate the effects of wheat flour substitution with tigernut flour. Brown variety of tigernut was sorted and dried in a cabinet dryer at $60^{\circ} \mathrm{C}$ for $72 \mathrm{hrs}$ and was processed into flour and blended with wheat flour at different ratios of 100:0; 90:10; 80:20; 70:30; 60:40; 50:50, 40:60, 30:70, 20:80, 10:90 respectively. The flour blends were analyzed for proximate composition, functional properties, pasting properties and rheological properties (viscosity). Data obtained were subjected to analysis of variance and significant means were separated using Duncan multiple range test. Moisture, crude protein, crude fibre, total ash, crude fat and carbohydrate ranged from 4.11 to $10.35 \%$, 4.72 to $12.28 \%, 2.82$ to $9.81 \%, 0,51$ to $0.78 \%, 0.84$ to $15.61 \%$ and 50.26 to $73.25 \%$ respectively. Significant differences exist in the functional, pasting properties and viscosity of wheat and tigernut flour blends. As the substitution of tigernut flour increases, the hardness, crust and crumb moisture of the sausage increases during storage. The result of this study shows that tigernut has the advantage of improving the crude fat, total ash and crude fibre of the blends. Substitution of tigernut flour to wheat flour had a significant effect on all the functional properties of the flour blends. The pasting properties of wheat and tigernut flour blends were affected thereby leading to decreases in the peak, trough, breakdown, final viscosity, setback and peak time. The viscosity of wheat and tigernut flour blends is relatively too high and this suggests that the flour blends will be useful in production of baked products.
\end{abstract}

Keywords: wheat flour, tigernut flour, sausage roll

\section{Introduction}

Tigernut (Cyperus esculentus $\mathrm{L}$ ) is an underutilized crop which belongs to the division Magnoliophyta, Class-liliopsida, order-cyperales and family-cyperaceae and was found to be a cosmopolitan perennial crop of the same genus as the papyrus plant. Tigernut is commonly known as earth almond, chufa, chewfa and Zulu nuts. It is known in Nigeria as Aya in Hausa, Ofio in Yoruba and Akiausa in Igbo where three varieties (black, brown and yellow) are cultivated. Among these, only two varieties, yellow and brown, are readily available in the market. The yellow variety is preferred to all other varieties because of its inherent properties like its bigger size, attractive colour and fleshier body. The yellow variety also yields more milk upon extraction, contains lower fat and more protein and possesses less anti-nutritional factors especially polyphenols (Okafor et al., 2003). Tigernut has been demonstrated to be a rich source of good quality oil (Dubois et al., 2007; Yeboah et al., 2012) and contain a moderate amount of protein (Oladele and Aina, 2007). It is a source of some useful minerals such as potassium, phosphorus and calcium (Bixquert-jimenez, 2003) as well as vitamin E and C (Belewu and Belewu, 2007). In addition, tigernut has been demonstrated to contain higher essential amino acids than those proposed in the protein standard by the FAO/WHO (1985) for satisfying adult needs (Bosch et al., 2005). It has been reported to be high in dietary fibre content (Alegria-Toran and Farre-Rovira, 2003) which could be effective in treatment and prevention of many diseases including colon cancer (Adejuyitan et al., 2009), coronary heart disease (Chukwuma et al., 2010), obesity, diabetes, gastrointestinal disorders (Anderson et al., 2009b) and losing weight (Borges et al., 2008).

Sausage is a cylindrical meat product usually made from ground meat, often pork, beef, or veal, along with salt, spices and additives. Typically, a sausage is formed in a casing traditionally made from intestine, but sometimes from synthetic materials, aside from the meat product, the other major ingredient required for the production of sausage is the wheat flour used for the sausage pastry casing. Sausage roll is a snack popular in Nigeria and Africa; it is formed into tubes around sausage meat and glazed with egg or milk before being baked. It is usually kneaded, cut into squares and folded before baking.

In Nigeria, the utilization of tigernut is highly limited in spite of the fact that tigernut is cultivated widely in the Northern part of the country. Several information are available on the use of wheat-based composite flour in Nigeria comprising buckwheat (Lin et al., 2009), plantain (Mepba et al., 2007), modified corn starch (Woo and Seib, 2002), waxy corn starch (Lee et al., 2001; Morita et al., 2002), sunflower flour (Biljan and Bojana, 2008), chick pea (Manuel et al., 2008), bean flour, tigernut of brown and yellow variety (Ade-omowaye et al., 2008; Oke et al., 2016). Tigernut seeds are cheap and readily available but grossly underutilized and need more attention because of its nutritional qualities such as high fibre. Recent application of tigernut has been concentrated on tigernut (brown and yellow variety) flour for bread making (Ade- 
omawaye et al., 2008 and Oke et al., 2017), biscuit (Zahra and Ahmed, 2014). Information is limited on the storability of sausage of from wheat and brown variety of tigernut flour blends. Although tigernut is an underutilized seed and need more attention because of its nutritional qualities such as high fibre. Therefore, the aim of this study is to determine the proximate composition, functional, rheological properties of wheat and tigernut flour blends and storage studies of sausage produced from wheat and tigernut.

\section{Materials and methods}

\section{Materials}

Dry tigernut (brown variety) was locally purchased from Kuto market Abeokuta, Ogun state. Wheat flour and other essential ingredients like baking flour, sugar, nutmeg, salt, butter was purchased at Kuto market in Abeokuta, Ogun state.

\section{Tigernut Flour Preparation}

The method described by Ade-omowaye et al. (2008) was used in the preparation of brown variety of tigernut flour. Dry tigernuts (Cyperus esculentus) was sorted manually to remove unwanted materials like stones, pebbles and other foreign seeds. The cleaned nuts were dried in a cabinet dryer at $60^{\circ} \mathrm{C}$ for $72 \mathrm{hrs}$. Dried nuts was milled using laboratory hammer mill (Fritsch, D-55743, Idar-Oberstein-Germany) and the milled sample was sieved (using $250 \mu \mathrm{m}$ screen) to obtain the flour. The tigernut flour was packed and sealed in polyethylene bags at ambient temperature $(26 \pm 20 \mathrm{C})$ and $760 \mathrm{mmHg}$ until further analysis.

\section{Blend Formulation of Wheat and Tigernut Flour}

Eleven composite flours were prepared by blending wheat flour (WF) and tigernut flour (TF) in the ratios of 100:0, 90:10, 80:20, 70:30, 60:40, $50: 50,40: 60,30: 70,20: 80,10: 90$ and $0: 100$ respectively.

\section{Proximate Composition of Wheat and Tigernut Flour Blends}

Proximate composition of the wheat and tigernut flour (moisture content, crude protein, crude fat, total ash and crude fibre) was analyzed using the method described by (AOAC, 2000). Carbohydrate contents of the flour samples were calculated by difference method.

\section{Functional Properties of Wheat and Tigernut Flour Blends}

\section{Determination of Bulk density}

Bulk density was determined using the method described by Wang and Kinsella (1976). Ten grams of sample were weighed into $50 \mathrm{ml}$ graduated measuring cylinder. The sample was packed by gently tapping the cylinder on the bench top. The volume of the sample was recorded.

$$
\text { Bulk density }\left(\frac{g}{m l}\right)=\frac{\text { Weight of sample }}{\text { Volume of sample after tapping }}
$$

\section{Determination of Water absorption capacity}

This was determined using methods described by Beuchat (1977). One gram sample was weighed into $25 \mathrm{ml}$ graduated conical centrifuge tubes and about $10 \mathrm{ml}$ of water added. The suspensions were allowed to stand at room temperature $\left(30 \pm 2{ }^{\circ} \mathrm{C}\right)$ for $1 \mathrm{hr}$. The suspension was centrifuge at $2000 \mathrm{rpm}$ for 30 minute. The volume of water on the sediment was measured and the water absorbed expressed as per cent water absorption based on the original sample weight.

\section{Determination of Oil absorption capacity}

Oil absorption capacity of the flour samples were determined by Beuchat (1977) methods. $1 \mathrm{~g}$ of the flour was mixed with $10 \mathrm{ml}$ of oil in a centrifuge tube and allowed to stand at room temperature $\left(30 \pm 2{ }^{\circ} \mathrm{C}\right)$ for $1 \mathrm{~h}$. It was then centrifuged at $2000 \mathrm{rpm}$ for $30 \mathrm{~min}$. The volume of water or oil on the sediment water was measured. Oil absorption capacities were calculated as $\mathrm{ml}$ of oil absorbed per gram of flour.

\section{Determination of swelling power and solubility index}

The swelling power and solubility index was determined using the method described by Takashi and Seib (1988). One grams of flour was weighed into a $50 \mathrm{ml}$ centrifuge tube. $50 \mathrm{ml}$ of distilled water was added and mixed gently. The slurry was heated in a water bath at $90{ }^{\circ} \mathrm{C}$ for 15 minutes. During heating the slurry was stirred gently to prevent clumping of the flour. On completion, the tube containing the paste was centrifuged at 3,000rpm for 10 minutes using a centrifuge machine. The supernatant was decanted immediately after centrifuging. The weight of the sediment was taken and recorded. The moisture content of sediment gel was thereafter determined to get dry matter content of the gel.

$$
\begin{aligned}
& \text { Swelling power }=\frac{\text { Weight of wet mass sediment }}{\text { Weight of dry matter in the gel }} \\
& \text { Solubility index }(\%)=\frac{\text { Weight of dry solids after drying }}{\text { Weight of sample }} \times 100
\end{aligned}
$$

\section{Dispersibility}

This was determined by the method described by kulkarni et al. (1991). $10 \mathrm{~g}$ of flour was suspended in $100 \mathrm{ml}$ measuring cylinder and distilled water was added to reach a volume of $100 \mathrm{ml}$. The set up was stirred vigorously and allowed to settle for $3 \mathrm{hr}$. The volume of settled particles was recorded and subtracted from 100. The difference was reported as percentage dispersibility.

\section{Pasting Properties of Wheat and Tigernut Flour Blends}

Pasting properties was determined with a Rapid Visco Analyzer (RVA TECMASTER, perten instrument-2122833, Australia).Three grams of sample was weighed into a dried empty canister, and then $25 \mathrm{ml}$ of distilled water was dispensed into the canister containing the sample. The suspension was thoroughly mixed properly so that no lumps were obtained and the canister was fitted into the rapid visco analyzer. A paddle was then placed into the canister and the test proceeded immediately automatically plotting the characteristic curve. Parameters estimated was peak viscosity, setback viscosity, final viscosity, trough, breakdown viscosity, pasting temperature and time to reach peak viscosity. 


\section{Rheological Properties of Wheat and Tigernut Flour using Brookfield Viscometer}

The method described by Muhammad and Sagir (2011) was used for rheological properties of wheat and tigernut flour. The viscosity of the flour blends samples was measured in triplicates at controlled temperature of $50^{\circ} \mathrm{C}$ using a digital rotational Brookfield viscometer (Brookfield Engineering Laboratories, Middleboro, USA, Model DV - E). These readings were taken per samples at 20,40 and 1 min rotation at each speed (50, 60 and $100 \mathrm{rpm})$. Spindle \#4 was used for all measurements. A $500 \mathrm{ml}$ beaker was used for the measurement with the viscometer guard leg on. The samples were poured into a beaker to reach a level that covers the immersion groove on the spindle shaft. The viscosities of the products was measured at temperature between $25-26^{0} \mathrm{C}( \pm 1)$.

\section{Preparation of Sausage Roll}

The method described by Kohajdova and Karovicova (2008) with little modification was used for the preparation of sausage roll. A straight dough process was used for the preparation of sausage roll, Ingredients such as butter $(100 \mathrm{~g})$, sugar $(1 \mathrm{~g})$, salt $(1 \mathrm{~g})$, water $(15 \mathrm{~mL})$, baking powder $(2 \mathrm{~g})$ and tigernut flour was added in appropriate proportion to each of the flour blends and control flour. The substitution of tigernut flour into wheat flour was $(10 \%, 20 \%, 30 \%, 40 \%, 50 \%, 60 \%, 70 \%$, $80 \%$ and $90 \%$ ) for making sausage roll dough. The blends were mixed with ingredients in a spiral mixer (for 5 minutes). Water was added to the flour inside the spiral mixer and kneaded for 3 minutes. The dough was scaled and shaped. Baking was done at a temperature of $220^{\circ} \mathrm{C}$ for 13 minutes.

\section{Storage Studies of Wheat-Tigernut sausage roll}

The sausage were packed into airtight Ziploc bags (Johnson and Son, Inc. WI53403-2236, USA) and stored at room temperature, hardness of sausage, crumb and crust moisture were monitored at intervals of 24h, 4days.

\section{Texture profile analysis of Wheat-Tigernut sausage roll}

The method described by Abdelghafor et al. (2011) was used. Hardness of sausage crumb was determined using Texture Profile Analysis (TPA). Sausage was sliced transversely using a kitchen knife to obtain uniform slices of $4 \mathrm{~cm}$ thickness. Sausage slices were taken from the centre of each roll to evaluate the crumb texture. By using a vernier caliper, a sample of $8 \mathrm{~cm}$ height was taken. The TPA was performed using a Testometric Universal Testing Machine (M500-25KN,UK). The computer was set for test works software and an appropriate test was selected for the TPA analysis. Samples were placed in between the two load cell plates of the machine, and the load cell was slowly brought down to a lower level, so that it touches the sample. Parameters like height, diameter, speed, the percent compression (30\%), and number of cycles (two) were inputted before starting compression of the sample. Then, the load cell was slowly moved downwards, compressing the sample in $5 \mathrm{sec}$ and waiting between first and second compression cycles. The TPA was performed on 6 rolls sample of sausage for 4 days.

\section{Crumb and Crust Moisture of Wheat-Tigernut Sausage Roll}

The method described by Shittu et al. (2009) was used. Crumb and crust moisture were determined by cutting one gram of crumb from the middle of sausage slice, and one gram each were cut from 4 edges of the slice and at the centre to make five gram and the outer crust of sausage samples were carefully scrapped with kitchen type sausage knife. The samples were dried at $105^{\circ} \mathrm{C}$ for $3 \mathrm{~h}$. It was removed from the oven, cooled in a dessicator and after cooling, the weight was taken and returned into oven for another 30 mins; it was cooled and weighed again until constant weight.

\section{Statistical analyses}

Data obtained were subjected to statistical analysis. Means were subjected to Analysis of variance (ANOVA) were determined using SPSS Version 21.0 and the differences between the mean values were evaluated at $\mathrm{p}<0.05$ using Duncan's multiple range test.

\section{Results and discussion}

\section{Proximate Composition of Wheat and Tigernut Flour Blends}

The proximate composition of wheat and tigernut flour is presented in Table 1. Moisture content of flour is indicative of dry matter of the flour. Significant difference $(p<0.05)$ was observed in the moisture content, crude fat, total ash, crude fibre, crude protein and carbohydrate. The moisture content of wheat and tigernut flour ranged from 4.11 to $10.35 \%$. Flour produced from $100 \%$ tigernut had the lowest moisture content while flour produced from $100 \%$ wheat flour had the highest moisture content. The low moisture content obtained in this study can be attributed to lower moisture content of the tigernut flour thereby reducing the moisture content of the flour blends. The lower the initial moisture content of a product to be stored, the better the storage stability of the product, since high moisture content can enhance microbial growth which leads to deterioration of foods (Akanbi et al., 2011), this indicates that wheat and tigernut flour blends will stay longer on the shelf. The crude fat ranges from 0.84 to $15.61 \%$ with $100 \%$ tigernut flour having the highest fat content while $100 \%$ wheat flour had the lowest fat content. The increase in the fat content obtained in this study can be attributed to the high fat content in tigernut. The result obtained for the crude fat content in this study was close to the findings of Ade-omowaye et al. (2008). The total ash content of a food material could be used as index of mineral constituents of the food because ash is the inorganic residue remaining after the water and organic matter have been removed by heating in the presence of an oxidizing agent (Sanni et al., 2008). The total ash ranged from 0.51 to $6.78 \%$. $100 \%$ wheat flour had lowest total ash content while $100 \%$ tigernut flour had the highest total ash content. The high value of total ash content from $100 \%$ tigernut flour in this study suggests that the flour will be rich in mineral. The total ash content of $100 \%$ tigernut flour obtained in this study was higher than the values of $5.63 \%$ reported for tigernut flour by Oke et al., (2016). The crude fibre increased from 2.82 to $9.82 \%$ with $100 \%$ wheat flour having the lowest crude fibre and $100 \%$ tigernut flour having the highest crude fibre. The increase in the crude fibre content obtained in this study can be attributed to the high fibre content of the tigernut flour. However, Adejuyitan et al. (2009) also reported tigernut to be high in fibre. The crude protein of wheat and tigernut flour blend decreased from 12.28 to 4.72 as the substitution of tigernut increase. The decrease in the protein content can be attributed to low protein 
content of tigernut (Addy and Eteshola, 1994). The carbohydrate for wheat and tigernut flour was high. The carbohydrate ranges between 50.26and $76.93 \%$ with wheat flour substituted with tigernut flour at $40 \%$ having the highest carbohydrate while $100 \%$ tigernut flour had the lowest carbohydrate. Carbohydrate supplies energy to cells such as brains, muscles and blood. It contribute to fat mechanism and spare proteins as an energy source and act as mild natural laxative for human beings and generally add to the bulk of the diet (Gordon, 2000; Gaman and Sherrington, 1996).

Table 1. Proximate composition of wheat and tigernut flour (\%)

\begin{tabular}{|l|l|l|l|l|l|l|}
\hline WF:TF & $\begin{array}{l}\text { M o i s t u r e } \\
\text { Content }\end{array}$ & Crude Fat & Total Ash & Crude Fiber & Crude Protein & Carbohydrate \\
\hline $100: 0$ & $10.35 \pm 0.41^{\mathrm{i}}$ & $0.84 \pm 0.03^{\mathrm{a}}$ & $0.51 \pm 0.02^{\mathrm{a}}$ & $2.82 \pm 0.08^{\mathrm{a}}$ & $12.28 \pm 0.22^{\mathrm{h}}$ & $73.25 \pm 0.71^{\mathrm{bc}}$ \\
\hline $90: 10$ & $9.5 \pm 0.13^{\mathrm{h}}$ & $2.09 \pm 0.11^{\mathrm{a}}$ & $0.65 \pm 0.02^{\mathrm{ab}}$ & $3.12 \pm 0.08^{\mathrm{a}}$ & $10.32 \pm 0.65^{\mathrm{g}}$ & $74.33 \pm 0.99^{\mathrm{c}}$ \\
\hline $80: 20$ & $9.23 \pm 0.10^{\mathrm{h}}$ & $2.72 \pm 0.08^{\mathrm{a}}$ & $0.68 \pm 0.01^{\mathrm{bc}}$ & $4.04 \pm 0.03^{\mathrm{b}}$ & $9.68 \pm 0.08^{\mathrm{f}}$ & $73.66 \pm 0.11^{\mathrm{c}}$ \\
\hline $70: 30$ & $8.5 \pm 0.39^{\mathrm{g}}$ & $3.33 \pm 0.17^{\mathrm{a}}$ & $0.73 \pm 0.01^{\mathrm{bc}}$ & $4.10 \pm 0.02^{\mathrm{b}}$ & $8.06 \pm 0.07^{\mathrm{e}}$ & $74.29 \pm 0.79^{\mathrm{c}}$ \\
\hline $60: 40$ & $7.82 \pm 0.18^{\mathrm{f}}$ & $3.28 \pm 0.24^{\mathrm{a}}$ & $0.82 \pm 0.08^{\mathrm{bc}}$ & $4.14 \pm 0.02^{\mathrm{b}}$ & $7.02 \pm 0.12^{\mathrm{d}}$ & $76.93 \pm 0.44^{\mathrm{d}}$ \\
\hline $50: 50$ & $6.92 \pm 0.02^{\mathrm{e}}$ & $5.62 \pm 0.70^{\mathrm{a}}$ & $1.02 \pm 0.02^{\mathrm{d}}$ & $4.20 \pm 0.02^{\mathrm{b}}$ & $6.34 \pm 0.04^{\mathrm{c}}$ & $75.92 \pm 0.68^{\mathrm{d}}$ \\
\hline $40: 60$ & $6.44 \pm 0.13^{\mathrm{de}}$ & $6.86 \pm 0.15^{\mathrm{a}}$ & $1.15 \pm 0.04^{\mathrm{de}}$ & $5.92 \pm 0.08^{\mathrm{c}}$ & $5.92 \pm 0.08^{\mathrm{bc}}$ & $73.72 \pm 0.23^{\mathrm{c}}$ \\
\hline $30: 70$ & $6.16 \pm 0.08^{\mathrm{cd}}$ & $7.11 \pm 0.03^{\mathrm{a}}$ & $1.18 \pm 0.01^{\mathrm{e}}$ & $6.14 \pm 0.03^{\mathrm{c}}$ & $5.63 \pm 0.01^{\mathrm{b}}$ & $73.78 \pm 0.11^{\mathrm{c}}$ \\
\hline $20: 80$ & $5.93 \pm 0.18^{\mathrm{bc}}$ & $7.91 \pm 0.30^{\mathrm{a}}$ & $1.19 \pm 0.01^{\mathrm{e}}$ & $6.61 \pm 0.14^{\mathrm{cd}}$ & $4.99 \pm 0.1^{\mathrm{a}}$ & $73.39 \pm 0.73^{\mathrm{bc}}$ \\
\hline $10: 90$ & $5.64 \pm 0.23^{\mathrm{b}}$ & $9.16 \pm 0.08^{\mathrm{a}}$ & $1.24 \pm 0.01^{\mathrm{e}}$ & $7.29 \pm 0.11^{\mathrm{d}}$ & $4.64 \pm 0.08^{\mathrm{a}}$ & $72.05 \pm 0.51^{\mathrm{b}}$ \\
\hline $0: 100$ & $4.11 \pm 0.21^{\mathrm{a}}$ & $15.61 \pm 0.77^{\mathrm{a}}$ & $6.78 \pm 0.21^{\mathrm{e}}$ & $9.82 \pm 1.21^{\mathrm{e}}$ & $4.72 \pm 0.57^{\mathrm{a}}$ & $50.26 \pm 0.59^{\mathrm{a}}$ \\
\hline
\end{tabular}

Mean values with different superscripts within the same column are significantly different $(p<0.05)$; WF- wheat flour, TF- tigernut flour

\section{Functional Properties of Wheat and Tigernut Flour Blends}

The functional properties of wheat and tigernut flour blends are presented in Table 2. The functional properties are those parameters that determine the application and end use of food materials for various food products. The bulk density of the blends ranges from 0.61 to $0.72 \mathrm{~g} / \mathrm{ml} .100 \%$ wheat flour and wheat flour substituted with tigernut flour at $10 \%$ had the highest bulk density while $100 \%$ tigernut flour had the lowest bulk density. The decrease in the bulk density as substitution of tigernut flour increases could be related to its high fibre content which could reduce the heaviness of the composite flour and that of the products and consequently the transportation costs and post handling of the same. Significant differences $(p<0.05)$ were observed in the water absorption capacity of the flour blends. The water absorption capacity ranged between 118.77 and $148.39 \%$. The water absorption capacity is an index of the ability of a flour product to associate with water under a condition where water is limiting (Omueti et al., 2009). High water absorption capacity is attributed to loose structure of the starch polymers while low value indicates the compactness of the molecular structure. The high water absorption capacity obtained in this study could be useful in food systems such as bakery products which require hydration to improve handling characteristics. The oil absorption capacity decreased from 151.6 to $130.5 \%$ with $100 \%$ wheat flour having the highest oil absorption capacity and $100 \%$ tigernut flour having the lowest oil absorption capacity. Oil absorption capacity is an important property in food formulations because fat improves the flavour and mouthfeel of foods (Aremu et al., 2007). The decrease in oil absorption capacity of wheat and tigernut flour blends obtained in this study might be due to low hydrophobic protein which shows superior binding of lipids. Significant differences $(p<0.05)$ were observed in the swelling power and solubility index of wheat and tigernut flour blends. The swelling power and solubility index ranged from 10.45 to $19.96 \mathrm{~g} / \mathrm{g}$ and 1.10 to $1.71 \%$ respectively with $100 \%$ tigernut flour having the lowest swelling

The result obtained for the result of swelling power and solubility index were not in agreement with the findings of Oke et al. (2016). Safo-kantanka and Acquistucci (1996) stated that the swelling power of a starch based food is an indication of the strength of the hydrogen bonding between the granules. Swelling is a measure of swollen starch granule and food eating quality is connected with retention of swollen starch granules (Richard et al., 1991). Furthermore, the report described swelling power as a factor of the ratio of amylose to amylopectin. Solubility reflects the extent of intermolecular cross bonding within the granule (Hari et al., 1989). Significant differences ( $p<0.05$ ) exist in the dispersibility of wheat and tigernut flour blends; it ranges between 70.39 and $79.39 \%$. Dispersibility is a measure of the reconstitutability of flour or flour blends in water. The higher the dispersibility the better the flour reconstitutes in water (Kulkarni et al., 1991). However, since the dispersibility value for all the wheat and tigernut flour blends are relatively high, it implies that they will reconstitute easily to give a fine consistency dough during mixing as reported by Adebowale et al. (2008). 
Table 2. Functional properties of wheat and tigernut flour blends

\begin{tabular}{lcccccc}
\hline WF:TF & Bulk Density & WAC & OAC & SP & SI & Dispersibility \\
& $(\mathrm{g} / \mathrm{ml})$ & $(\%)$ & $(\%)$ & $(\mathrm{g} / \mathrm{g})$ & $(\%)$ & $(\%)$ \\
& & & & & & \\
\hline $100: 0$ & $0.72 \pm 0.01^{\mathrm{e}}$ & $148.39 \pm 0.76^{\mathrm{d}}$ & $151.6 \pm 0.52^{\mathrm{i}}$ & $19.96 \pm 0.20^{\mathrm{i}}$ & $1.71 \pm 0.03^{\mathrm{h}}$ & $76.19 \pm 0.13^{\mathrm{abc}}$ \\
$90: 10$ & $0.72 \pm 0.00^{\mathrm{e}}$ & $146.34 \pm 0.47^{\mathrm{d}}$ & $149.7 \pm 0.16^{\mathrm{h}}$ & $18.11 \pm 0.13^{\mathrm{h}}$ & $1.67 \pm 0.01^{\mathrm{h}}$ & $72.31 \pm 0.21^{\mathrm{ab}}$ \\
$80: 20$ & $0.68 \pm 0.00^{\mathrm{d}}$ & $143.51 \pm 1.24^{\mathrm{d}}$ & $147.38 \pm 0.65^{\mathrm{g}}$ & $17.77 \pm 0.20^{\mathrm{h}}$ & $1.61 \pm 0.01^{\mathrm{g}}$ & $70.39 \pm 0.40^{\mathrm{a}}$ \\
$70: 30$ & $0.68 \pm 0.00^{\mathrm{d}}$ & $134.24 \pm 11.48^{\mathrm{c}}$ & $145.17 \pm 0.30^{\mathrm{f}}$ & $16.97 \pm 0.06^{\mathrm{g}}$ & $1.53 \pm 0.04^{\mathrm{f}}$ & $79.39 \pm 0.40^{\mathrm{d}}$ \\
$60: 40$ & $0.68 \pm 0.00^{\mathrm{cd}}$ & $132.07 \pm 4.37^{\mathrm{bc}}$ & $144.18 \pm 0.23^{\mathrm{ef}}$ & $15.37 \pm 0.36^{\mathrm{f}}$ & $1.47 \pm 0.03^{\mathrm{e}}$ & $77.78 \pm 0.16^{\mathrm{cd}}$ \\
$50: 50$ & $0.66 \pm 0.00^{\mathrm{c}}$ & $127.05 \pm 0.40^{\mathrm{abc}}$ & $143.03 \pm 0.71^{\mathrm{e}}$ & $14.56 \pm 0.28^{\mathrm{e}}$ & $1.41 \pm 0.02^{\mathrm{d}}$ & $74.68 \pm 0.08^{\mathrm{ad}}$ \\
$40: 60$ & $0.65 \pm 0.00^{\mathrm{b}}$ & $130.48 \pm 0.52^{\mathrm{ab}}$ & $139.88 \pm 0.23^{\mathrm{d}}$ & $14.25 \pm 0.18^{\mathrm{de}}$ & $1.33 \pm 0.01^{\mathrm{c}}$ & $74.60 \pm 0.40^{\mathrm{abc}}$ \\
$30: 70$ & $0.64 \pm 0.02^{\mathrm{b}}$ & $126.16 \pm 0.25^{\mathrm{abc}}$ & $137.91 \pm 0.73^{\mathrm{c}}$ & $13.98 \pm 0.21^{\mathrm{d}}$ & $1.54 \pm 0.03^{\mathrm{f}}$ & $75.87 \pm 0.48^{\mathrm{bcd}}$ \\
$20: 80$ & $0.66 \pm 0.00^{\mathrm{c}}$ & $124.52 \pm 0.58^{\mathrm{ab}}$ & $138.14 \pm 0.71^{\mathrm{c}}$ & $13.22 \pm 0.41^{\mathrm{c}}$ & $1.2 \pm 0.02^{\mathrm{b}}$ & $70.42 \pm 0.36^{\mathrm{a}}$ \\
$10: 90$ & $0.62 \pm 0.00^{\mathrm{a}}$ & $120.98 \pm 0.23^{\mathrm{a}}$ & $131.65 \pm 0.44^{\mathrm{b}}$ & $12.02 \pm 0.12^{\mathrm{b}}$ & $1.17 \pm 0.02^{\mathrm{b}}$ & $75.38 \pm 6.38^{\mathrm{bcd}}$ \\
$0: 100$ & $0.61 \pm 0.00^{\mathrm{a}}$ & $118.77 \pm 0.20^{\mathrm{a}}$ & $130.50 \pm 0.48^{\mathrm{a}}$ & $10.45 \pm 0.33^{\mathrm{a}}$ & $1.10 \pm 0.00^{\mathrm{a}}$ & $78.16 \pm 0.07^{\mathrm{cd}}$ \\
\hline
\end{tabular}

Mean values with different superscripts within the same column are significantly different $(p<0.05)$; WF- Wheat Flour, TF- Tigernut Flour, WAC-Water Absorption Capacity, OAC-Oil Absorption Capacity, SP-Swelling Power, SOL-Solubility Index

\section{Pasting Properties of Wheat and Tigernut Flour Blends}

The pasting properties of wheat and tigernut flour blends are presented in Table 3. The peak viscosity ranged between 17.21 and 257.13RVU, where the $100 \%$ wheat flour had the highest value, while $100 \%$ tigernut flour had the lowest value. Peak viscosity is the maximum attainable viscosity during heating, it also indicates the water binding capacity of the starch, and however a significant difference $(p<0.05)$ was observed in the peak viscosity of the composite flour. Trough viscosity is the maximum viscosity at the constant temperature phase of the rapid visco analyzer profile and the ability of the phase to withstand breakdown during cooling. The trough strength showed that there was a significant difference $(\mathrm{p}<0.05)$ in all the samples. Similarly $100 \%$ wheat flour had the highest value of 153.83 RVU while $100 \%$ tigernut flour had the lowest value of 16.13. The addition of tigernut flour lowers the trough viscosity of wheat flour and this implies that the blends may not find good application in the food system where high paste stability during cooling is required (Adegunwa et al., 2015). The breakdown viscosity ranged from 1.25 to $103.08 \mathrm{RVU}$. There was decrease in the breakdown viscosity of the wheat-tigernut flour blends and this could be attributed to the relatively high fibre content, which could decrease the stability of the food product when stored at high temperature. The higher the breakdown value the higher the ability to remain undisrupted when subjected to long period of constant high temperature and ability to withstand beak down during cooking (Akanbi et al., 2009). The final viscosity ranged from 26.54to 263.17 RVU. $100 \%$ wheat flour had the highest final viscosity while $100 \%$ tigernut flour had the lowest breakdown viscosity. There was decrease in the final viscosity of wheat-tigernut composite flour; this could be due to the relatively high fibre value of the added tigernut with subsequent negative effect on the quality of starch (Brooks and Schizsach, 1999). The setback values decreased as the substitution of tigernut increases. $100 \%$ wheat flour had the highest value (109.42RVU) while 100\% tigernut flour had the lowest value (10.75RVU). The Setback region is the phase on the pasting curve after cooling the sample to $50^{\circ} \mathrm{C}$. It is the phase where retrogradation of starch molecules occurs. High setback value is known to be associated with a cohesive paste, while a low value is an indication that the paste is not cohesive with less tendency to retrograde upon cooling. Peak time is the time at which the peak viscosity occurred in minutes and it is a measure of the cooking time of the flour. Peak time value ranged between 5.05 and $6.34 \mathrm{~min}$ with wheat flour substituted with tigernut flour at $10 \%$ recorded the highest value for peak time suggesting more processing time, while wheat flour substituted with tigernut flour at $80 \%$ recorded the least peak time. Pasting temperature ranged from 69.44 to $85.50^{\circ} \mathrm{C}$. The pasting temperature gives an indication of the minimum temperature needed to cook a sample, which also have indication on the energy cost of preparing a product. The results indicated an increase in the pasting temperature with increase in tigernut flour substitution. 
Table 3. Pasting properties of wheat and tigernut flour blends

\begin{tabular}{|c|c|c|c|c|c|c|c|}
\hline WF:TF & $\begin{array}{l}\text { Peak Viscosity } \\
\text { (RVU) }\end{array}$ & $\begin{array}{l}\text { Trough } \\
\text { Viscosity } \\
\text { (RVU) }\end{array}$ & $\begin{array}{l}\text { Breakdown } \\
\text { Viscosity } \\
\text { (RVU) }\end{array}$ & $\begin{array}{l}\text { Final } \\
\text { Viscosity } \\
\text { (RVU) }\end{array}$ & $\begin{array}{l}\text { Setback } \\
\text { Viscosity } \\
\text { (RVU) }\end{array}$ & $\begin{array}{l}\text { Peak Time } \\
\text { (Mins) }\end{array}$ & $\begin{array}{l}\text { Pasting } \\
\text { Temperature } \\
\text { (C) }\end{array}$ \\
\hline 100:0 & $257.13 \pm 0.06 \mathrm{k}$ & $153.83 \pm 0.24^{\mathrm{e}}$ & $103.08 \pm 0.12^{\mathrm{k}}$ & $263.17 \pm 0.12^{\mathrm{k}}$ & $109.42 \pm 0.24^{\mathrm{k}}$ & $6.32 \pm 0.06^{\mathrm{f}}$ & $69.44 \pm 0.13^{\mathrm{b}}$ \\
\hline $90: 10$ & $204.42 \pm 1.65^{\mathrm{j}}$ & $122.00 \pm 2.24^{\mathrm{de}}$ & $79.54 \pm 0.18^{j}$ & $229.5 \pm 0.24^{\mathrm{j}}$ & $105.71 \pm 0.06^{\mathrm{j}}$ & $6.34 \pm 0.01^{\mathrm{f}}$ & $70.37 \pm 0.82^{\mathrm{b}}$ \\
\hline $80: 20$ & $181.29 \pm 0.06^{\mathrm{i}}$ & $115.93 \pm 77.53^{\mathrm{abc}}$ & $70.42 \pm 0.24^{\mathrm{i}}$ & $197.96 \pm 0.18^{\mathrm{i}}$ & $87.00 \pm 0.12^{\mathrm{i}}$ & $5.94 \pm 0.01^{\mathrm{de}}$ & $71.13 \pm 0.11^{\mathrm{b}}$ \\
\hline $70: 30$ & $170.54 \pm 0.88^{\mathrm{h}}$ & $105.54 \pm 0.29^{\text {cde }}$ & $63.71 \pm 0.65^{\mathrm{h}}$ & $196.63 \pm 0.53^{\mathrm{h}}$ & $90.42 \pm 0.12^{\mathrm{h}}$ & $6.06 \pm 0.02^{\mathrm{e}}$ & $82.95 \pm 0.22^{\mathrm{d}}$ \\
\hline $60: 40$ & $150.25 \pm 0.12^{\mathrm{g}}$ & $89.33 \pm 0.59^{\mathrm{bcd}}$ & $60.38 \pm 0.06^{\mathrm{g}}$ & $169.58 \pm 0.12^{\mathrm{g}}$ & $79.25 \pm 0.94^{\mathrm{g}}$ & $5.85 \pm 0.07^{\mathrm{d}}$ & $80.62 \pm 0.12^{\mathrm{d}}$ \\
\hline $50: 50$ & $120.50 \pm 0.83^{\mathrm{f}}$ & $69.17 \pm 0.24^{\mathrm{ad}}$ & $51.00 \pm 0.12^{\mathrm{f}}$ & $123.63 \pm 0.18^{\mathrm{f}}$ & $54.58 \pm 0.24^{\mathrm{f}}$ & $5.28 \pm 0.07^{\mathrm{bc}}$ & $81.00 \pm 0.42^{\mathrm{c}}$ \\
\hline $40: 60$ & $88.92 \pm 0.00^{\mathrm{e}}$ & $53.29 \pm 0.06^{\mathrm{abc}}$ & $35.96 \pm 0.53^{\mathrm{e}}$ & $97.96 \pm 0.06^{\mathrm{e}}$ & $44.50 \pm 0.24^{\mathrm{e}}$ & $5.30 \pm 0.04^{\mathrm{c}}$ & $80.62 \pm 0.12^{\mathrm{c}}$ \\
\hline $30: 70$ & $75.17 \pm 0.24^{\mathrm{d}}$ & $48.46 \pm 0.18^{\mathrm{ab}}$ & $26.83 \pm 0.24^{\mathrm{d}}$ & $86.46 \pm 0.18^{d}$ & $37.33 \pm 1.30^{\mathrm{d}}$ & $5.26 \pm 0.02^{\mathrm{bc}}$ & $81.93 \pm 0.53^{\mathrm{cd}}$ \\
\hline $20: 80$ & $48.83 \pm 0.24^{\mathrm{c}}$ & $34.42 \pm 0.12^{\mathrm{ab}}$ & $14.58 \pm 0.12^{\mathrm{c}}$ & $64.21 \pm 0.18^{\mathrm{c}}$ & $30.17 \pm 0.24^{\mathrm{c}}$ & $5.05 \pm 0.04^{\mathrm{a}}$ & $82.00 \pm 0.71^{\mathrm{cd}}$ \\
\hline 10:90 & $32.88 \pm 0.18^{\mathrm{b}}$ & $26.50 \pm 0.59^{\mathrm{b}}$ & $6.92 \pm 0.35^{\mathrm{b}}$ & $46.38 \pm 0.88^{b}$ & $19.75 \pm 0.12^{\mathrm{b}}$ & $5.10 \pm 0.14^{\mathrm{ab}}$ & $83.20 \pm 0.06^{\mathrm{d}}$ \\
\hline 0:100 & $17.21 \pm 0.06^{\mathrm{a}}$ & $16.13 \pm 0.06^{\mathrm{a}}$ & $1.25 \pm 0.12^{\mathrm{a}}$ & $26.54 \pm 0.06^{\mathrm{a}}$ & $10.75 \pm 0.47^{\mathrm{a}}$ & $5.34 \pm 0.19^{c}$ & $85.50 \pm 2.12^{\mathrm{a}}$ \\
\hline
\end{tabular}

Mean values with different superscripts within the same column are significantly different $(p<0.05)$; WF- wheat flour, TF- tigernut flour

\section{Viscosity of Wheat and Tigernut Flour Blends}

The viscosity of wheat and tigernut flour blends is presented in Table 4 . The results shows that there is significant differences ( $\mathrm{p}<0.05)$ among the sample for speed 50,60 and 100. At speed 50 and 60rpm, the value ranged from 508 to $2356 \mathrm{cp}$ and 470 to $2113 \mathrm{cp}$ respectively, $100 \%$ wheat flour had the lowest viscosity while wheat flour substituted with tigernut flour at 50\% had the lowest viscosity at speed 50 and 60rpm. At speed $100 \mathrm{rpm}$ the value ranged from 386 to $1669 \mathrm{cp}$ with $100 \%$ wheat flour having the highest viscosity while wheat flour substituted with tigernut flour at $70 \%$ had the lowest viscosity. The high viscosity exhibited by wheat-tigernut flour blends shows that the samples has better water binding capacity.

Table 4. Viscosity of wheat and tigernut flour blends

\begin{tabular}{|l|l|l|l|}
\hline WF:TF & $\begin{array}{l}50 \mathrm{rpm} \\
(\text { Centipose })\end{array}$ & $\begin{array}{l}60 \mathrm{rpm} \\
(\text { Centipose) }\end{array}$ & $\begin{array}{l}100 \mathrm{rpm} \\
(\text { Centipose })\end{array}$ \\
\hline $100: 0$ & $508 / 12.7^{\mathrm{a}}$ & $470 / 14.1^{\mathrm{a}}$ & $386 / 19.3^{\mathrm{c}}$ \\
\hline $90: 10$ & $967 / 15.3^{\mathrm{b}}$ & $816 / 17.3^{\mathrm{bc}}$ & $739 / 20.0^{\mathrm{b}}$ \\
\hline $80: 20$ & $1448 / 33.1^{\mathrm{c}}$ & $1146 / 36.0^{\mathrm{d}}$ & $1004 / 40.4^{\text {bc }}$ \\
\hline $70: 30$ & $1968 / 49.2^{\mathrm{d}}$ & $1670 / 50.1^{\mathrm{e}}$ & $1142 / 57.1^{\mathrm{d}}$ \\
\hline $60: 40$ & $2040 / 39.6^{\mathrm{e}}$ & $1925 / 53.4^{\mathrm{f}}$ & $1574 / 60.4^{\mathrm{e}}$ \\
\hline $50: 50$ & $2356 / 58.9^{\text {ef }}$ & $2113 / 63.4^{\mathrm{g}}$ & $1564 / 78.2^{\mathrm{e}}$ \\
\hline $40: 60$ & $2118 / 45.5^{\mathrm{d}}$ & $1886 / 49.8^{\text {ef }}$ & $1599 / 52.2^{\mathrm{e}}$ \\
\hline $30: 70$ & $1779 / 33.8^{\text {de }}$ & $1711 / 37.1^{\text {ef }}$ & $1669 / 40.4^{\mathrm{f}}$ \\
\hline $20: 80$ & $1441 / 27.3^{\mathrm{c}}$ & $1402 / 29.9^{\mathrm{c}}$ & $1186 / 32.4^{\text {cd }}$ \\
\hline $10: 90$ & $1148 / 23.4^{\text {bc }}$ & $1069 / 24.1^{\mathrm{b}}$ & $1001 / 26.9^{\mathrm{bc}}$ \\
\hline $0: 100$ & $756 / 18.9^{\mathrm{b}}$ & $700 / 22.9^{\mathrm{b}}$ & $540 / 27.0^{\mathrm{a}}$ \\
\hline
\end{tabular}

Mean values with different superscripts within the same column are significantly different $(p<0.05)$; WF- Wheat flour, TF- Tigernut flour 


\section{Texture Profile Analysis of Wheat-Tigernut Sausage Roll (Hardness)}

The changes in hardness of wheat-tigernut sausage roll are presented in Table 5. As storage days increase, the hardness of wheat-tigernut sausage roll increased and significant differences $(p<0.05)$ were observed throughout the days of storage. Sausage roll produced from wheat and tigernut flour from Day 0, Day 1, Day 2 and Day 3 ranged from 82.8 to $437.5 \mathrm{~N}, 74.1$ to $609.7 \mathrm{~N}, 151.7$ to $817.6 \mathrm{~N}$ and 126.5 to 914.2 respectively. Sausage roll produced from $100 \%$ wheat flour had the lowest hardness for Day 0, Day 1, Day 2 and Day 3 while sausage roll produced from wheat flour substituted with tigernut at $90 \%$ had the highest hardness for Day 0, Day 1, Day 2 and Day 3 respectively. Hardness is mainly attributed to the amylose and amylopectin matrix which contribute to overall texture of a baked product (Schiraldi and Fessas, 2000). Starch polymers begin to change during the baking process and during storage. The increase obtained for the hardness of wheat-tigernut sausage roll in this study is caused mainly by starch retrogradation, formation of cross-linkages between starch and gluten chains, and water migration towards the crust of the sausage roll during storage (Karaoglu and Kotancilar, 2006).

Table 5. Changes in hardness of wheat-tigernut sausage roll during storage

\begin{tabular}{lllll}
\hline WF:TF & Day 0 & Day 1 & Day 2 & Day 3 \\
\hline $100: 0$ & $82.8 \pm 0.01^{\mathrm{a}}$ & $74.1 \pm 0.02^{\mathrm{b}}$ & $151.7 \pm 0.03^{\mathrm{a}}$ & $126.5 \pm 0.01^{\mathrm{a}}$ \\
$90: 10$ & $113.0 \pm 0.23^{\mathrm{b}}$ & $144.9 \pm 0.01^{\mathrm{a}}$ & $166.7 \pm 0.04^{\mathrm{b}}$ & $134.1 \pm 0.01^{\mathrm{a}}$ \\
$80: 20$ & $176.3 \pm 0.00^{\mathrm{ab}}$ & $178.3 \pm 0.04^{\mathrm{d}}$ & $202.1 \pm 0.01^{\mathrm{a}}$ & $172.7 \pm 0.01^{\mathrm{ab}}$ \\
$70: 30$ & $240.4 \pm 0.11^{\mathrm{f}}$ & $202.2 \pm 0.01^{\mathrm{a}}$ & $257.1 \pm 0.02^{\mathrm{b}}$ & $193.9 \pm 0.01^{\mathrm{ab}}$ \\
$60: 40$ & $256.5 \pm 0.12^{\mathrm{f}}$ & $224.2 \pm 0.01^{\mathrm{a}}$ & $372.0 \pm 0.02^{\mathrm{ab}}$ & $210.5 \pm 0.02^{\mathrm{b}}$ \\
$50: 50$ & $265.7 \pm 0.01^{\mathrm{e}}$ & $247.3 \pm 0.07^{\mathrm{c}}$ & $382.6 \pm 0.01^{\mathrm{a}}$ & $252.7 \pm 0.03^{\mathrm{b}}$ \\
$40: 60$ & $308.7 \pm 0.02^{\mathrm{bc}}$ & $287.5 \pm 0.01^{\mathrm{c}}$ & $396.8 \pm 0.01^{\mathrm{b}}$ & $307.9 \pm 0.01^{\mathrm{b}}$ \\
$30: 70$ & $362.6 \pm 0.01^{\mathrm{d}}$ & $297.1 \pm 0.02^{\mathrm{d}}$ & $423.6 \pm 0.01^{\mathrm{b}}$ & $433.4 \pm 0.02^{\mathrm{b}}$ \\
$20: 80$ & $418.9 \pm 0.04^{\mathrm{e}}$ & $314.5 \pm 0.01^{\mathrm{a}}$ & $562.8 \pm 0.02^{\mathrm{c}}$ & $559.6 \pm 0.01^{\mathrm{a}}$ \\
$10: 90$ & $437.5 \pm 0.01^{\mathrm{ab}}$ & $609.7 \pm 0.12^{\mathrm{a}}$ & $817.6 \pm 0.03^{\mathrm{a}}$ & $914.2 \pm 0.12^{\mathrm{b}}$ \\
\hline
\end{tabular}

Mean values with different superscripts within the same column are significantly different $(p<0.05)$;

WF: Wheat Flour, TF: Tigernut Flour

\section{Crumb and Crust Moisture of Wheat-Tigernut Sausage Roll}

The crust and crumb moisture of wheat-tigernut sausage roll during the days of storage are presented in Figure 1 and 2 . The crust moisture of wheat-tigernut sausage roll from Day 0- Day 3 ranged from 22.05 to $26.23 \%, 22.96$ to $26.84 \%, 23.38$ to $27.65 \%, 23.61$ to $28.37 \%, 24.21$ to $28.98 \%, 25.64$ to $30.05 \%, 26.03$ to $30.75 \%, 26.21$ to $31.22 \%, 27.93$ to $32.96 \%$ and 28.35 to $34.72 \%$ for wheat flour (100\%), $10 \%, 20 \%, 30 \%, 40 \%$, $50 \%, 60 \%, 70 \%, 80 \%$ and $90 \%$ respectively. An increase was observed in the crust moisture throughout the storage days. Sausage roll produced from 100\% wheat flour had the lowest crust moisture for Day 0, Day 1, Day 2 and Day 3 while sausage roll produced from wheat flour substituted with tigernut at 90\% had the highest crust moisture for Day 0, Day 1, Day 2 and Day 3 respectively. During the storage process, the crust became soggy and there is loss of crispness of the crust. The increase in the moisture content of the crust can be attributed to the redistribution of moisture from the crumb to the crust during the storage of sausage roll (Pateras, 1998). The crumb moisture of wheat-tigernut sausage roll from Day 0-Day 3 ranged from 30.07 to $35.65 \%, 29.62$ to $34.88 \%, 29.15$ to $32.98 \%, 28.54$ to $32.38 \%, 27.48$ to $31.23 \%, 26.30$ to $30.75 \%, 25.41$ to $30.02 \%$, 24.95 to $28.98 \%, 23.35$ to $27.55 \%$ and 22.92 to $26.97 \%$ for wheat flour (100\%), $10 \%, 20 \%, 30 \%, 40 \%, 50 \%, 60 \%, 70 \%, 80 \%$ and $90 \%$ respectively. There was also an increase in the crumb moisture throughout the storage days. This is an indication that there was less migration of water from the crumb to the crust. The result obtained for the crumb moisture content was not in agreement with the findings of Oke et al. (2017).

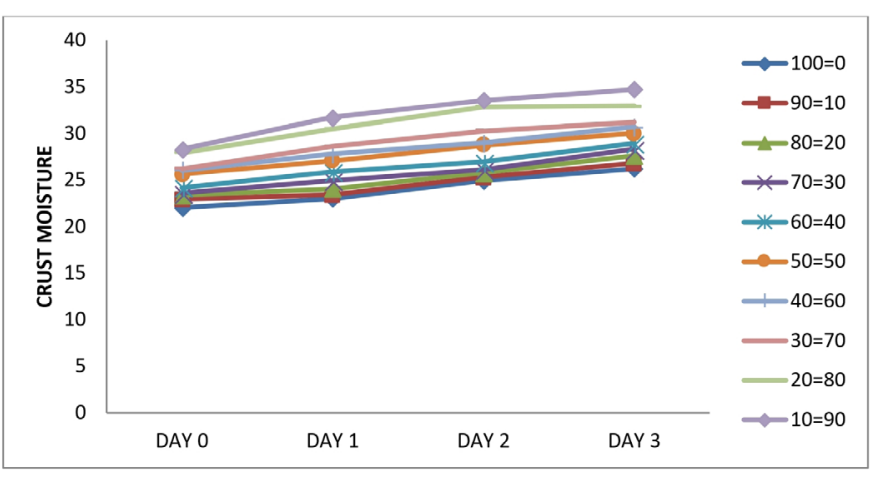

Figure 1. Changes in crust moisture of wheat-tigernut sausage roll during storage

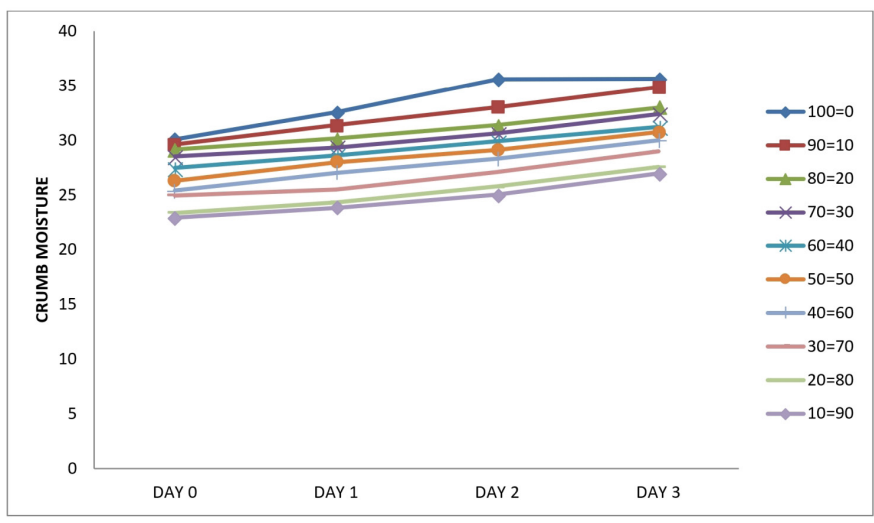

Figure 2. Changes in crumb moisture of wheat-tigernut sausage roll during storage 


\section{Conclusions}

The result of this study shows that tigernut has the advantage of improving the crude fat, total ash and crude fibre of the blends. Substitution of tigernut flour to wheat flour had a significant effect on all the functional properties of the flour blends. The pasting properties of wheat and tigernut flour blend were affected thereby leading to decreas- es in the peak, trough, breakdown, final viscosity, setback and peak time. The viscosity of wheat and tigernut flour blends is relatively too high and this suggests that the flour blends is useful in production of baked products. Addition of tigernut flour increases the hardness, crust and crumb moisture of wheat-tigernut sausage roll during storage days. Further studies should be carried out on the microbiological analysis of wheat-tigernut sausage roll during storage.

\section{References}

Adddy E.O, Eteshola E. (1994) Nutritive value of a mixture of tigernut tubers (Cyperus esculentusL) and baobab seeds (AdansoniadigitataL). Journal of Science Food and Agriculture, 35 437-440.

Abdelghafor R.F, Mustafa A.I, Ibrahim A.M.H, Krishnan P.G. (2011) Quality of bread from composite flour of sorghum and hard white winter wheat. Advance Journal of Food Science and Technology, 3(1) 9-15.

Adebowale, A. A., Sanni, L.O., Onitilo, M.O. (2008) Chemical composition and pasting properties of tapioca grit from different cassava varieties and roasting method. African Journal of Food Science, 2 77-82.

Adegunwa, M.O., Adeniyi, O.D., Adebowale, A.A., Bakare, H.A. (2015) Quality evaluation

of kokoro from maize-pigeon pea flour blends. Journal of Culinary Science and Technology, 13 200-213.

Adejuyitan J.A., Otunola, E.T., Akande, E.A., Bolariwa, I.F., Oladokun, F.M. (2009) Some physicochemical properties of flour obtained from fermentation of tigernut(Cyperusesculentus) sourced from a market in Ogbomoso, Nigeria. African Journal of Food Science, 351 - 55.

Ade-omowaye, B.I.O., Akinwande, B.A. Bolarinwa , I.F., Adebiyi, A.O. (2008) Evaluation of tigernut (Cyperus esculentus) - wheat composite flour and bread. African Journal of Food Science, $287-89$.

Akanbi, T.O., Nazamid, S., Adebowale, A.A. (2009) Functional and pasting properties of tropical bread fruit starch from Ile Ife Nigeria. International Food Research Journal, 16 151- 157.

Akanbi, T.O., Nazamid, S., Adebowale, A.A., Farooq, A., Olaoye, A.O. (2011) Breadfruit starch-wheat flour noodles: preparation, proximate compositions and culinary properties. International Food Research Journal, 18 1283-1287.

Anderson, J.W., Baird, P., Davis, R.H., Ferreri, S., Knudtson, M., Koraym A (2009) Health Benefits of Dietary Fibre. Nutrition Review, 67 $188-205$.

AOAC. (2000) Official Methods of Analysis (17 th ed.) Washington, DC: The Asociation of Official Analytical Chemists.

Aremu, M.O., Olaofe, O., Akintayo, E.T. (2007) Functional properties of some Nigerian varieties of legume seed flours and flour concentration effect on foaming and gelation properties. Journal of Food Technology, 5 (2) 109-115.

Belewu, M.A., Belewu, K.Y. (2007) Comparative physio-chemical evaluation of tigernut, soybean and coconut milk sources. International Journal of Agriculture and Biology,9 785-787.

Beuchat, L.R. (1977) Functional and electrophoretic characteristics of succinylated peanut flour protein. Journal of Agriculture and Food Chemistry, $25258-261$.

Biljan,S., Bojana, F. (2008). Nutritional and sensory evaluation of wheat bread supplemented with oleic-rich sunflower seed. Food Chemistry, 108 119-129.

Bizquert-Jimennez, M. (2003) Horchata and Health, Healthy properties and in deenfermedades

Digestive Prevention. Valencian Studies Foundation, Ministry of Agriculture, Fisheries and Food.

Borges, O. Gonclaves, B., Sgeoeiro, L., Correia, P., Silva, A. (2008) Nutritional quality of chestnut cultivars from Portugal. Food Chemistry, 106 $976-984$.

Bosch L., Alegeria, A., Farre R. (2005) RPHPLC determination of tigernut and orgreataminocid contents-Food Science Technology International, $1133-40$.

Brooks, M.A., Schizsach, U. (1999) Food science and technology, abstracts. International Food Info Services (IFIS), 4(70) 67- 74.

Chukwuma, E.R., Obioma, N., Christopher, O.I. (2010) The phytochemical composition and some biochemical effects of Nigerian tigernut $(C y$ perus esculentus L.) tuber. Pakistan Journal of Nutrition, 9 (7) 709 - 715.

Dubois, V., Breton, S. Linder, M., Fanni, J., Partmentier, M. (2007) Fatty acid profiles of 80

vegetable oils with regard to their nutritional potential. European Journal of Lipid Science Technology, 109720 - 73.

FAO (Food and agriculture organization) World Health Organization. (1985) Expert Consultation Energy and Protein Requirement. Geneva, Switzerland.

Gaman, P.M., Sherrington, K.B. (1996) The Science of Food. $4^{\text {th }}$ ed. Reel Educational and Professional Publisher Ltd, Oxford, pp 125-136.

Gordon, M.N. (2000) Contemporary Nutrition: Issues and Insights. $4^{\text {th }}$ ed. Mc-Graw Hill Companies, New York, pp102-256. 
Hari, P.K., Aargs, S., Garys, S.K. (1989) “Gelatinization of starch and modified starch” Starke, 41(3) 88-91.

Joy-Toran, A., Farre-Rovira, R. (2003) Horchata and Health, issues nutritional and dietetics.

Valencia: Valencia Foundation of Advanced Studies, Department of Agriculture, Fisheries and Food.

Karaoglu, M.M., Kotancilar, H.G. (2006) Effect of part-baking storage and re-baking process on the quality of white pan bread. International Journal of Food Science and Technology, 41(Suppl. 2) 108-114.

Kohajdová, Z., Karovicová, J. (2008) Influence of hydrocolloids on quality of baked goods. Acta Scientiarum Polonorum, Technologia Alimentaria, 7(2) 43-49.

Kulkani, K.D., Kulkani, D.N., Ingle, U.M. (1991) Sorghum maltbased weaning formulations preparation, functional properties and nutritive values. Food and Nutritional Bulletin, 13(4) 322-327.

Lee, M.R., Swanson, B.G., Baik, B.K. (2001) Influence of amylase content on properties of

wheat starch and bread making qualities of starch and gluten blends. Cereal Chemistry, 78 701- 706.

Lin, L., Liu H, Yu Y, Lin S., Mau J. (2009) Quality and antioxidant property of buckwheat enhanced wheat bread. Food Chemistry, $37461-467$.

Mepba, H.D, Eboh, L., Nwaojigwa S.U. (2007) Chemical composition, functional and baking properties of wheat- plantain composite flours. African Journal of Food Nutrition and Development, 7(1) 1-22.

Morita, N., Maeda, T., Miyazaki, M., Yamamori, M., Miura, H., Ohtsuka, I. (2002) Dough and baking properties of high amylase and waxy wheat flours. Cereal Chemistry, 79 491- 495.

Muhammad, S., Saghir, A. S. (2011) Analysis of viscosity of jamun fruit juice, squash and jam at different compositions to ensure the suitability of processing applications. International Journal of Plant Physiology and Biochemistry, 3(5) 89-94.

Odoemelan, S.A. (2003) Chemical composition and functional properties of conophor nut (tetracarpidiumconophorum) flour. International Journal of Food Science and Technology, 38 729-734.

Okaka, J.C., Potter, N.N. (1979) Sensory, nutritional and storage properties of cowpea powders processed to reduce beany flavor. Journal of Food Science, 44 1539-1542.

Oke, E.K., Idowu, M.A., Omoniyi, S.A. (2016) Proximate, functional, pasting and rheological properties of wheat- tiger nut composite flour. Annals Food Science and Technology,

17(2) 411-420.

Oke, E.K., Idowu, M.A., Sobukola O.P., Bakare, H.A. (2017) Quality attributes and storage

stability of bread from wheat-tigernut composite flour. Journal of Culinary Science and Technology, 1-14.

Omueti, O., Otegbayo, B., Jaiyeola, O., Afolabi, O. (2009) Functional properties of complementary diets developed from soybean (Glycine max), groundnut (Arachis hypogeal) and crayfish (Macrobrachiumspp). Journal of Environmental, Agricultural and Food Chemistry, 8 (8) 563-573.

Oladele, A.K., Aina, J.O. (2007) Chemical composition and functional properties of flour produced from two varieties of tigernut (Cyperus esculentus). African Journal of Biotechnology, 6 2473-2476.

Pateras, I.M.C. (1998) Bread Spoilage and Staling. In S. P. Cauvain \& L. S. Young (Eds.), Technology of breadmaking (p. 240). United Kingdom: Blackie Academic \& Professional. Richard, J.R., Asauka, M.A., Blanshard, J.N.V. (1991) The Physiochemical Properties of Cassava Starch. Tropical Science, 31 189-207.

Safo-Kantanka, K.O., Acquistucci, R. (1996) The physico-chemical properties of cassava starch in relation to the texture of the cooked root. Ghana Journal of Agricultural Science 28/29 69-80.

Sanni, L. O., Adebowale, A. A., Maziya-Dixon, B., Dixon, A. G. O. (2008) Chemical composition and pasting properties of CMD resistant cassava clones planted at different locations. Journal of Food and Agriculture and Environment 6(2) 97-104.

Schiraldi, A., Fessas, D. (2000) Mechanism of Staling. In C. Pavinee, Vodovotz, (eds). Bread Staling, New York: CRC Press, Inc. P. 2-10.

Takashi, S., Seib, P.A. (1988) Paste and gel properties of prime corn and wheat starches with and without nativelipids. Journal of Cereal Chemistry, $65474-480$.

Wang, J.C., Kinsella, J.E. (1976) Functional properties of novel proteins; alfalfa leaf protein. Journal of Food Science, $41286-289$.

Woo, K.S., Seib, P.A. (2002) Cross linked resistant starch: preparation and properties. Cereal Chemistry, 79 819-825.

Yeboah, S.O., Mitei, Y.C.,Ngila, J.C., Wessjohann, L., Schmidt, J. (2012) Compositional and structural studies of the oils from two edible seeds: tiger nut, Cyperus esculentum, and asiato, Pachira insignis, from Ghana. Food Research International, $47259-266$.

Zahra, S.A., Ahmed, M.S.H. (2014) Exploring the suitability of incorporating tiger nut flour as novel ingredient in gluten-free biscuit. Polish Journal of Food Nutrition and Science, 64(1) 27-33. 